\title{
Pencarian Jalur Terpendek Pada Permainan Pacman Menggunakan Algoritma A*
}

\author{
(The Shortest Path Search in Pacman Game Using A* Algorithm) \\ Darmawan Aditama, Nuniek Fahriani, Putri Aisyiyah Rakhma Devi \\ Progam Studi Teknik Informatika Fakultas Teknik \\ Universitas Muhammadiyah Gresik \\ Jl. Sumatera No.101, Gn. Malang, Randuagung, Kec. Gresik, Kabupaten Gresik, Jawa Timur 61121 \\ Email: awanaditama@umg.ac.id, nuniekfahriani@umg.ac.id, deviaisyiyah@umg.ac.id
}

\begin{abstract}
The development of Artificial Intelligence or commonly abbreviated (AI) is defined as the intelligence of scientific entities. Artificial Intelligence is one method on a computer controller that is used to take a decision and perform one of the actions. But not all controllers on the computer can see the entire location of the target, even in some games still using the location matrix to find the location of the nearest enemy, so that if there are so many targets it can make a miscalculation on the computer controller. Researchers try to use the A-Start algorithm $(A *)$ as Artificial Intelligence to see the development of the game if there are more than one target that must be killed by the enemy. So that in the future in a Pac-Man game can be given several targets (multiplayer).
\end{abstract}

Key words: Artificial Intelligence, Pacman Game, A*, Development

\section{Pendahuluan}

Metode kecerdasan buatan (Artificial Intelligence) adalah sistem kecerdasan yang sengaja dibangun dan ditunjukkan sebagai salah satu entitas buatan. Sistem seperti ini biasanya disebut komputer. Suatu kecerdasan dibuat atau sengaja diciptakan sehingga dapat diletakkan dalam mesin ataupun computer, sehingga komputer memiliki kemampuan yang dapat melakukan sebuah pekerjaan ataupun perintah layaknya seperti kemampuan manusia. Sistem pakar, game (permainan computer), metode logika fuzzy, jaringan syaraf tiruan dan robotika merupakan beberapa bidang yang menggunakan kecerdasan buatan sebagai dasar logika pada metodenya [1].

Benny Halim melakukan pengujian pada permainan pac-man dengan judul "penerapan fuzzy logic sugeno pada game pac-man". Logika fuzzy merupakan kecerdasan buatan yang dapat membuat computer menyelesaikan masalah perilaku sistem yang kompleks dan ketidakpastian yang diakibatkan oleh kemampuan dalam mengolah berbagai informasi numerik dari beberapa variabel yang telah ukur. Logika fuzzy telah banyak diterapkan sebagai metode dalam pengambilan keputusan pada perilaku komputer dan pada perilaku dalam game. Sehingga Benny berfokus pada tingkah laku enemy (ghost) selama permainan berlangsung [2].
Dikarenakan hal tersebut peneliti mencoba memberikan sentuhan kecerdasan buatan yang berbeda untuk menganalisa dampak Kecerdasan buatan dengan algoritma $A^{*}$ pada permainan dengan genre arcade yaitu pacman.

Algoritma $A^{*}$ adalah algoritma yang digunakan sebagai salah satu metode pencarian dari jalur yang terpendek atau istilahnya adalah pathfinding. Pada deskripsi peneliti adalah proses pencarian rute/jalur terdekat dari suatu arena yang pada umumnya memiliki penghalang-penghalang (obstacle) dari arena tersebut. Terdapat beberapa penghalang seperti berupa tembok, batu, sungai, dan lain-lain. Goal dari pathfinding adalah sebagai cara mencari jalur yang lebih efisien dengan cara menghindari semua penghalang yang ada untuk menemukan target dan membunuhnya [2].

Pathfinding dapat diterapkan pada metode kecerdasan buatan ketika membuat game, seperti supaya kecerdasan buatan tersebut memiliki kemampuan untuk dapat mengejar semua musuh sehingga lebih efisien dan sedapat mungkin tidak terjun kesuangau maupun menabrak tembok dan dapat menghindari semua penghalang yang lain. Terdapat banyak sekali metode yang bisa digunakan dalam pathfinding, sedangkan pada penelitian ini penulis mencoba memberikan kemampuan pada enemy dengan menggunakan kecerdasan buatan seperti $A^{*}$.

Sehingga nantinya dapat dilihat apakah algoritma $A^{*}$ cukup baik digunakan dalam permainan arcade atau malah sebaliknya. Dengan melihat jumlah player dalam satu permainan. Dan kemampuan emeny dalam menemukan jalur terpendek untuk membunuh Penguna dari pemain.

\section{TINJAUAN PUSTAKA}

\section{A. Sejarah Kecerdasan Buatan}

Kecerdasan buatan adalah sebuah inovasi baru dalam ilmu pengetahuan. Kehadirannya telah ada semenjak telah diciptaknnya komputer, pada tahun 1940 dan 1950. kemampuan komputer atau mesin elektronika yang dapat menyimpan banyak informasi, dengan kemampuannya yang dapat memproses informasi dengan sangat cepatan dan tinggi melampaui semua kemampuan manusia. 
Alan turing pada tahun 1950, dia adalah seorang penggagas kecerdasan buatan sekaligus ahli dalam bidang matematika. Negara Inggris melakukan banyak sekali percobaan Turing (Turing Test) dengan menggunakan sebuah komputer melalui terminalnya yang ditempatkan pada jarak yang saling dengan berjauhan. Pada ujung salah satu satu terminal terdapat kecerdasan buatan dan pada ujung yang lain terdapat sebuah terminal yang juga terdapat seorang pengguna (user). Penguna tersebut tidak dapat mengetahui bahwasannya pada ujung terminal yang lain telah dipasang kecerdasan buatan. Sehingga mereka dapat berkomunikasi dengan memanfaatkan terminal yang berada di ujung dengan memberikan sebuah respon pada serangkaian pernyataan yang telah diajukan pada User. Sehingga penguna telah mengira kalau dia telah berkomunikasi dengan Penguna lainnya yang telah berada di terminal yang lain [3].

Turing memiliki anggapan bahwasannya jika mesin telah memiliki kemampuan kecerdasan buatan dan dapat membuat orang lainnya mempercayai bahwasannya dirinya dapat berkomunikasi bersama orang lain, maka dapat disimpulkan bahwasannya mesin yang memiliki kemampuan Kecerdasan buatan tersebut memiliki kecerdasan layaknya kecerdasan manusia.

Metode kecerdasan buatan merupkan suatu sistem kecerdasan yang telah sengaja dibangun dan ditunjukkan sebagai salah satu dari entitas buatan manusia. Sistem seperti ini biasanya disebut sebagai komputer. Suatu kecerdasan yang dibuat atau sengaja diciptakan sehingga dapat diletakkan dalam sebuah mesin ataupun pada komputer, sehingga computer tersebut memiliki kemampuan yang dapat melakukan sebuah pekerjaan ataupun perintah layaknya seperti kemampuan manusia. Sistem pakar, game (permainan computer), metode logika fuzzy, jaringan syaraf tiruan dan robotika merupakan beberapa bidang yang menggunakan kecerdasan buatan sebagai dasar logika pada metodenya [1].

Kecerdasan buatan adalah salah satu dari banyaknya perkembangan yang sangat penting pada abad ini. Hal ini telah memengaruhi kehidupan manusia dan kehidupan negara-negara yang selama ini memainkan peranan sangat penting dalam sejarah perkembangan pembuatan kecerdasan buatan, yang saat ini kemudian telah muncul sebagai salah satu Negara adijaya.

Pentingnya sebuah kecerdasan buatan telah memberikan efek besar bagi negara-negara yang telah berperan penting sejak tahun 1970. Para pemimpinpemimpin negara yang telah mengakui banyaknya potensi dari perkembangan kecerdasan buatan telah mengharapkan mendapatkan persetujuan dalam jangka panjang untuk berbagai sumber-sumber yang telah memerlukan dana yang sanagt besar. Negara Jepang adalah Negara yang pertama kali membuat percobaan itu. Negara jepang berusaha mengembangkan banyak sekali program peenlitian dengan sangat berambisi menemukan kecerdasan buatan yang dapat merubah seluruh hidup umat manusia.

\section{B. Definisi Kecerdasan Buatan}

Manusia memiliki kecerdasan atau kepandaian untuk menyelesaikan suatu permasalahan, karena sejak lahir manusia telah mempunyai kualitas dan kuantitas dalam ilmu pengetahuan dan pengalaman. Ilmu pengetahuan manusia didapat dari keinginannya belajar/studi. Semakin tinggi dan hinga tak terhitung ilmu pengetahuan yang dipunyai manusia, maka manusia akan lebih mudah/mampu dalam menyelesaikan suatu persoalan/permasalahan yang dihadapi. Namun bekal ilmu pengetahuan saja tidaklah mencukupi, sehingga manusia harus mampu melakukan semua penalaran dan memiliki kemampuan menyimpulkan berdasarkan ilmu pengetahuan dan berbagai pengalaman yang telah dipunyai [4].

Jika manusia tidak mempunyai kemampuan melakukan penalaran dengan sangat baik walaupun memiliki pengalaman yang sangat banyak sekali, maka manusia tidak akan mampu menyelesaikan suatu permasalahan dengan baik. Demikian juga jika manusia tidak memiliki kemampuan untuk melakukan penalaran yang sangat baik, namun juga tidak memiliki bekal yang cukup dalam ilmu pengetahuan dan pengalaman, maka manusia tersebut juga tidak akan meiliki kemampuan menyelesaikan suatu permasalahan dengan sangat baik. Sebuah mesin agar memiliki kecerdasan untuk bertindak dan berfikir seperti dan sebaik manusia, maka mesin tersebut harus dirancang dan dibuat memiliki basis pengetahuan dan kemampuan yang dapat digunakan untuk melakukan penalaran [3].

Kecerdasan buatan harus memiliki 2 bagian penting yg dibutuhkan ketika membuat sebuah aplikasi, game, system cerdas dan lain-lain dengan kecerdasan buatan $\left(\mathrm{A}^{*}\right)$ :

1. Basis pengetahuan (knowledge base) berisi banyak fakta-fakta, serta teori, dan penalaran yang saling terkoneksi antara satu dengan yang lainnya.

2. inference engine : merupakan suatu kemampuan menarik kesimpulan berdasarkan dari pengalaman yang dimiliki.

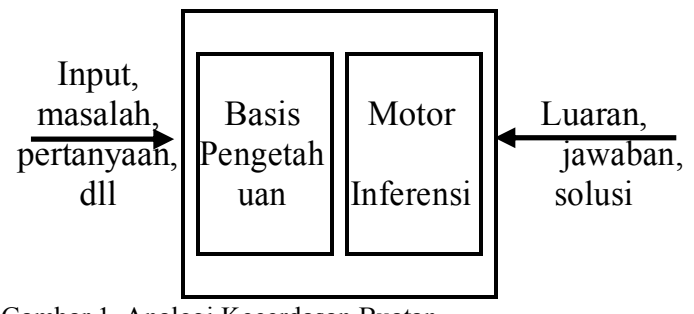

Gambar 1. Analogi Kecerdasan Buatan

\section{Kecerdasan Buatan versus Kecerdasan Alami}

a) Keunggulan dari kecerdasan buatan :

1. Kecerdasan buatan bersifat permanen. Artinya sebuah Kecerdasan yang alami dan bisa berubahubah karena tidak memiliki sifat manusia yang pelupa. Namun kecerdasan buatan tidak dapat berubah-ubah selama sistem atau komputer beserta programnya tidak berubah. 
2. Kecerdasan buatan sangat mudah untuk diduplikasi dan disebar luaskan. Sehingga dapat Mentransfer ilmu pengetahuan dari manusia ke manusia yang lain. Namun manusia sendiri membutuhkan proses yang begitu sangat lama, selain itu keahlian yang dimiliki manuai tidak akan pernah bisa untuk diduplikat dengan sangat lengkap. Oleh karena itu, jika suatu sistem cerdas yang telah ditanamkan bais pengetahuan, maka basis pengetahuan tersebut akan dapat pindahkan ke sistem yang lainnya seperti halnya suatu aplikasi sistem komputer dapat dipindahkan secara langsung ke komputer yang lainnya.

3. Harga lebih murah. Artinya kecerdasan buatan mampu menyediakan sebuah layanan sistem komputer yang akurat namun lebih murah dan mudah, dibandingkan dengan menggunakan sumber daya manusia untuk melakukan pekerjaan dalam jangka waktu yang panjang.

4. Kecerdasan buatan bersifat konsisten dikarenakan kecerdasan buatan adalah hasil pengembangan teknologi komputer modern, sedangkan sebuah kecerdasan alami tidak konsisten layaknya perilaku manusia yang sering berubah-ubah.

5. Sistem komputer dapat didokumentasikan. Menjadi sebuah kenyataan jika data atau informasi yang telah dibuat dengan komputer akan dapat didokumentasikan dengan sangat mudah hanya dengan cara menelusuri log/aktivitas dari sistem komputer tersebut. Namun kecerdasan alami sangatlah sulit untuk dapat direpreduksi.

6. Kecerdasan buatan cenderung cepat dan baik

b) Kelebihan dari kecerdasan alami manusia :

1. Manusia itu Kreatif : sejak lahir manusia telah memiliki suatu kemampuan untuk dapat menambahkan ilmu pengetahuan, sedangkan suatu kecerdasan buatan jika ingin menambahkan ilmu pengetahuan maka harus dilakukan proses yang rumit melalui sistem-sistem yang telah dibangun.

2. Manusia dimungkinkan untuk dapat memakai banyak pengalaman baik secara tidak langsung maupun langsung. Sedangkan untuk menambahkan pengalaman pada sistem kecerdasan buatan dilakukan dengan proses pelatihan menggunakan data input yang biasanya berupa data simbolik.

Pemikiran yang dimiliki manusia dapat digunakan secara tidak terbatas, sedangkan pada kecerdasan buatan (A*) harus sangat terbatas.

\section{Kecerdasan Buatan pada Aplikasi-Aplikasi Komersil}

Ruang lingkup dari kecerdasan buatan dalam kehidupan sehari-hari manusia, dengan berkembangnya banyak permasalahan yang dihadapi manusia, maka manusia harus berfikir untuk menggunakan berbagai sumber daya dengan lebih efisien. Untuk dapat melakukan hal tersebut, manusia membutuhkan banyak bantuan dengan kualitas dan kuantitas yang tinggi seperti sistem komputer.

Karena Dalam kehidupan manusia, sistem komputer telah banyak membantu pekerjaan manusia dalam berbagai bidang yang sesuai dengan yang dibutuhkan sehingga mendapatkan hasil yang lebih baik dari beberapa hasil pekerjaan sebelumnya. Namun seiring dengan berkembangannya teknologi, akan muncul banyak sekali peneliti yang memiliki tujuan untuk membuat sistem komputer agar menjadi lebih cerdas, sehingga komputer tersebut dapat menirukan pekerjaan manusia sehari-hari. kecerdasan buatan dibangun untuk dapat membantu pekerjaan manusia dalam berbagai bidang seperti berikut:

Expert system merupakan suatu sistem komputer yang digunakan sebagai tool untuk menyimpan pengetahuan dari para ahli/pakar. Oleh karena itu komputer dangan sistem pakar-nya memiliki keahlian untuk menyelesaikan berbagai persoalan manusia seperti halnya keahlian pakar yang ditirunya.

1. Komputer dengan sistem natural language processing (NLP) memungkinkan pengguna untuk saling berkomunikasi menggunakan bahasa sehari-hari, serpti memakai bahasa Jawa, Sunda, Indonesia, India, Jepang, Indonesia, srilanka, Inggris, dan lain sebagainya.

2. Komputer memiliki kemampuan speech recognition: yaitu manusia akan dapat berkomunikasi melalui perintah ucapan atau dengan perintah suara dengan komputer.

3. Elktronika dan Robotika memiliki sistem sensor.

4. Computer vision: Komputer dapat memahami gambar atau objek-objek.

5. Komputer akan dapat dipakai sebagai media tutor sehingga dapat melatih siswa dan mengajar siswa.

6. Playing Game.

\section{E. Beda Dari Kecerdasan Buatan Dengan Kecerdasan Alami}

MAlgoritma Kecerdasan (A*), Algoritma semacam ini adalah algoritma dengan metode Best First Search yang menggabungkan metode Uniform Cost Search dan metode Greedy Best-First Search. Suatu hasil yang akan dipertimbangkan $l(i)$ didapatkan dari hasil sesungguhnya dari $j(i)$ lalu ditambahkan hasil dari perkiraan $h(i)$. sehingga dalam notasi ilmu matematika dituliskan:

$$
l(i)=j(i)+h(i) \text {. }
$$

Masalah yang utama ketika membangun sebuah sistem berbasis Kecerdasan buatan adalah bagaimana cara/teknik mengkonversi suatu kondisi yang diberikan menjadi keadaan/kondisi lain yang diinginkan dengan menggunakan sekelompok perintah atau operasi.

Sama halnya dengan algortima dasar Best First Search, pada algoritma kecerdasan A* juga menerapkan/memakai perintah dua senarai yaitu "buka" dan "tutup". Akan ada tiga keadaan/state untuk setiap gen yang dibangkitkan, yaitu sudah dalam keadaan "buka", 
ataukah sudah pada keadaan "tutup", serta tidak dalam pada keadaan "buka" maupun keadaan "tutup". Untuk setiap keadaan, diberikan perintah-perintah yang berbeda [3].

Jika gen yang dibangkitkan pernah berada dikonsisi "buka", maka dilakukan pengecekan ulang apakah perlu untuk mengubahan parent ataukah gen yang dibangkitkan tidak bergantung pada nilai gennya melalui parent yang lama ataukah gen yang dibangkitkan bergantung pada parent baru. Jika gen yang dibangkitkan melalui parent baru maka parent memberikan nilai gen yang lebih kecil kepada gen yang dibangkitkan, maka akan dilakukan pengubahan pada parent. Namun jika pengubahan terhadap parent dilakukan, maka akan dilakukan juga perubahan pada nilai $j$ dan $l$ tersebut. Sehingga akan didapatkan gen untuk simpul yang terbaik (best node) [3].

Jika gen yang dibangkitkan sudah pernah berada pada kondisi "tutup", maka akan dilakukan sebuah pengecekan apakah perlu mengubahan nilai parent atau tidak. Jika iya, maka akan dilakukan perbaruan nilai $j$ dan $l$ pada gen yang dibangkitkan tersebut serta semua "anak cucunya" yang sudah pernah berada pada kondisi "buka". Dengan adanya perbaruan ini, maka gen yang dibangkitkan dan semua anak cucunya tersebut dapat memiliki kesempatan yang lebih tinggi untuk terpilih sebagai simpul yang terbaik (best node).

Jika gen yang dibangkitkan tidak berada pada kondisi "buka" maupun kondisi "tutup", maka gen yang dibangkitkan tersebut dimasukkan ke dalam kondisi "buka". Tambahkan gen yang dibangkitkan tersebut sebagai gen best node. Hitung biaya gen yang dibangkitkan tersebut dangan rumus $l^{\prime}=j+h^{\prime}$.

Contoh Penelusuran A* :

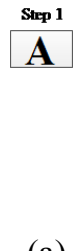

(a)

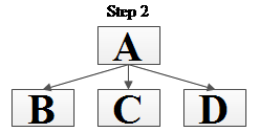

(b)

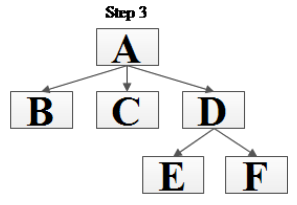

(c)
Gambar 2. Ilustrasi pohon penelusuran A*

Pada langkah awal, graf kondisinya seperti Gambar 2(a) yang merupakan suatu titik/node awal untuk proses penelusuran. Oleh karena itu node A dinyatakan sebagai node terbaik (best node) diinputkan kedalam list "buka". Hasil penelusuran dari node A ditemukan tiga buah noe yaitu B, C, dan D seperti ditunjukkan pada Gambar 2(b). Selanjutnya node A dinyatakan dengan kondisi "tutup" sebagai tanda bahwa node A telah pernah dikunjungi. Kemudian dari tiga node $\mathrm{B}, \mathrm{C}$ dan $\mathrm{D}$ dihitung nilai $[l(i)]$ dimana nilai $[l(i)]$ terkecil dipilih sebagai node kunjungan selanjutnya. Dalam hal ini, node $\mathrm{C}$ memiliki nilai terkecil maka selanjutnya node $\mathrm{C}$ menjadi kunjungan berikutnya. Kemudian semua suksesor C dibangkitkan hingga diperoleh node E dan F seperti ditunjukkan pada Gambar 2(c). Maka hasil penelusuran dari ilustrasi diatas adalah A-
C-F (Dalam hal ini bila pada node F telah ditemukan tujuan atau goal akhir) [5].

Algoritma kecerdasan A* telah Complete dan Optimal melalaui parameter $l(i)$. Fungsi heuristik yaitu suatu nilai yang menentukkan untuk setiap simpul yang dapat membimbing $A^{*}$ untuk menemukan berbagai penyelesaian yang diharapkan. Algoritma $A^{*}$ akan menemukan berbagai penyelesaian (jika memang ada penyelesaiannya/solusinya) dengan menggunakan fungsi heuristik. Artinya bahwa fungsi heuristik merupakan fungsi estimasi atau perkiraan yang biasa saja. Sehingga tidak ada rumus khusus dari fungsi heuristik dalam metode A*. Oleh karena itu, untuk setiap kasus akan mempunyai fungsi heuristik yang berbeda [5].

Algoritma kecerdasan $A^{*}$ dapat membangkitkan berbagai node yang kecil. Node-node ini kemudian akan disimpan gennya ke dalam beberapa list yang disiapkan berdasarkan urutan-urutan yang paling mendekati dengan penyelesaian terbaik yang diharapkan. Selanjutnya, node pertama pada list akan diambil, dibangkitkan gennya dan kemudian gen ini dapat disimpan kembali ke dalam list sesuai dengan urutan-urutan yang terbaiknya. List node ini kemudian disebut sebagai node terbuka (open node) [5]. Algoritma kecerdasan $A^{*}$ dapat menyelesaikan berbagai masalah menggunakan teori graf untuk perluasan ruang pencariannya. Dengan kata lain algoritma kecerdasan $A^{*}$ dapat digunakan sebagai proses menyelesaikan suatu permasalahan yang dapat direpresentasikan dengan graf. Algoritma kecerdasan $A^{*}$ adalah suatu algoritma yang memiliki kemampuan untuk berkembang atau memperluas wilayah dengan cara menerapkan suatu fungsi heuristik, algoritma ini dapat membuang berbagai langkah yang dirasa tidak perlu dengan cara mempertimbangkan bahwa langkah-langkah yang telah dibuang merupakan langkahlangkah yang tidak akan bisa mencapai solusi-solusi yang diharapkan.

Algoritma kecerdasan $A^{*}$ dapat menyelesaikan suatu masalah dengan menggunakan graf pada perluasan ruang. Sehingga $A^{*}$ dapat digunakan menyelesaikan suatu permasalahan yang dapat di representasikan dengan menggunkan graf. Algoritma kecerdasan $A^{*}$ merupakan sebuah algoritma yang sudah diperkaya, dengan cara menerapkan suatu system heuristik, algoritma ini dapat membuang suatu langkah-langkah yang tidak diperlukan dengan mempertimbangkan bahwa langkah-langkah yang telah dibuang pasti merupakan suatu langkah yang tidak dapat mencapai suatu solusi yang diharapkankan [6].

Algoritma kecerdasan buatan (A Star) merupakan salah satu dari algoritma pencarian dengan cara menganalisa input, $A *$ mengevaluasi beberapa jalur yang mungkin dapat dilewati dan dapat menghasilkan beberbagai solusi. Algoritma $\mathrm{A}^{*}$ merupakan algoritma komputer yang dapat digunakan secara luas dalam metode graph traversal. Dengan cara menemukan jalur serta proses untuk perencanaan jalur yang dapat dilewati dengan efisien di sekitar jalur (titik-titik) yang biasa disebut nodenode [7]. 


\section{Metode Penelitian}

\section{A. Metode Penelitian}

Tahap analisa system adalah tahapan penting terkait pembuatan system, karena pada tahap ini penulis mencoba berimajinasi terkait system yang bakal dicapai.

Dimana pada Pencarian Jalur Terpendek Pada Permainan Pacman Menggunakan Algoritma A* masih banyak dikembangkan. Karena pada permainan pacman mungkin akan terjadi tingkat kesulitan expert yang memungkinkan player tidak akan dapat mengalahkan ghost yang menjaga labirin.

\section{A.1. Sistem Kecerdasan Pada Permainan}

Dalam permainan Pacman terdapat system kecerdasan berupa kemampuan dari ghost yang dapat mengetahui lokasi dari player.

Namun ghost tersebut hanya memiliki kemampuan untuk mendeteksi musuh dalam radius tertentu sehingga cukup mudah untuk dilewati. Karena itu peneliti telah memberikan suatu kemampuan pada ghost berupa kecerdasan buatan yang dapat menemukan letak player secara lebih akurat.

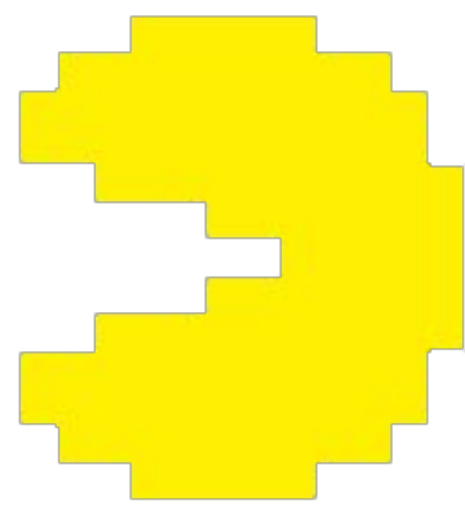

Gambar 3. Pacman

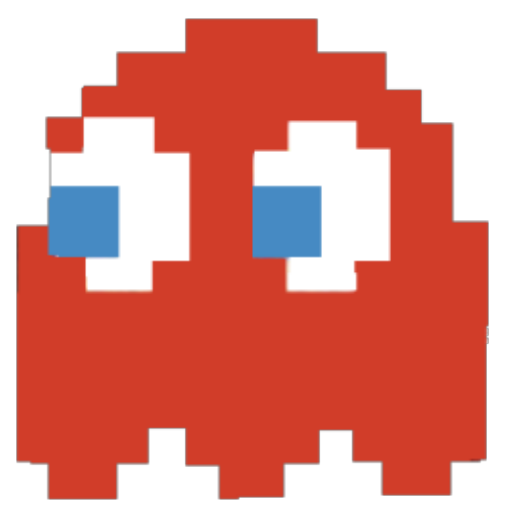

Gambar 4. Ghost

\section{A.2. Game Play}

Dalam permainan terdapat pacman (Gambar3) dan ghost (Gambar 4) yang dapat berjalan keatas, kebawah, kekanan, dan kekiri. Begitu pula dengan player. Jika player tersentuh oleh ghost, maka player akan mati dan permainan berakhir, namun ketika player dapat memakan buah energy maka sebaliknya. Player akan dapat membunuh ghost.

Untuk dapat melihat keberhasilan pemberian kecerdasan $A^{*}$ dalam permainan, maka dibuat desain simulasi (Gambar 5) yang nantinya dapat diambil datanya. Sehingga perlu dibuat rangkaian desain permainan yang menjadi tahapan terpenting untuk pengambilan data.

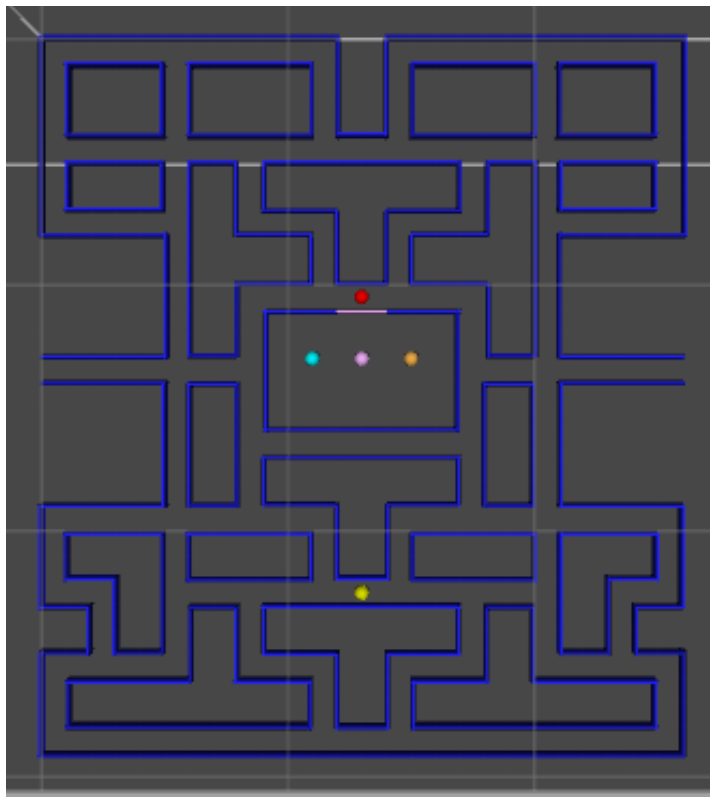

Gambar 5. Rancangan Labirin

Perlu juga dilakukan serangkaian uji coba dalam simulasi (Gambar 6, 7 dan 8) untuk melihat keberhasilan permainan jika menambahkan kecerdasan buatan $A^{*}$ pada ghost.

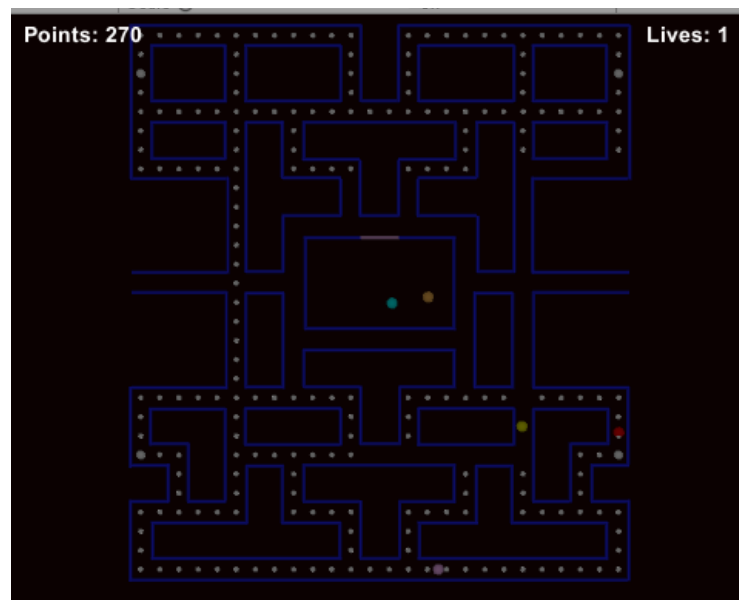

Gambar 6. Simulasi Kecerdasan Buatan 


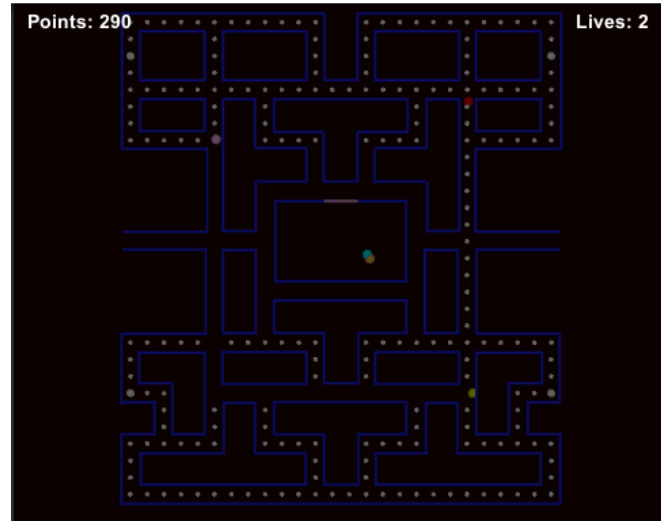

Gambar 7. Simulasi Pacman Memakan Energi

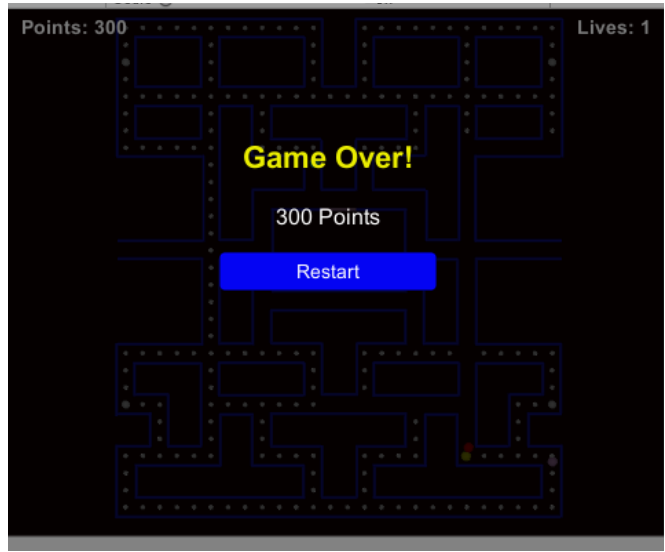

Gambar 8. Simulasi Game Over

\section{HASIL DAN PEMBAHASAN}

\section{A. Hasil Uji Coba}

Untuk mendapatkan hasil dari percobaan maka dibawah ini adalah tabel dan gambar hasil uji coba dari Pencarian Jalur Terpendek Pada Permainan Pacman Menggunakan Algoritma A*

\section{B. Tahap Uji Coba Permainan}

Pada tahapan ini terdapat beberapa gambar yang menunjukkan uji coba pada permainan beserta data yang dihasilkan. Gambar 9 menunjukkan desain 3D dari labirin yang dijadikan sebagai uji coba. Seluruh labirin menggunakan bidang 3D.

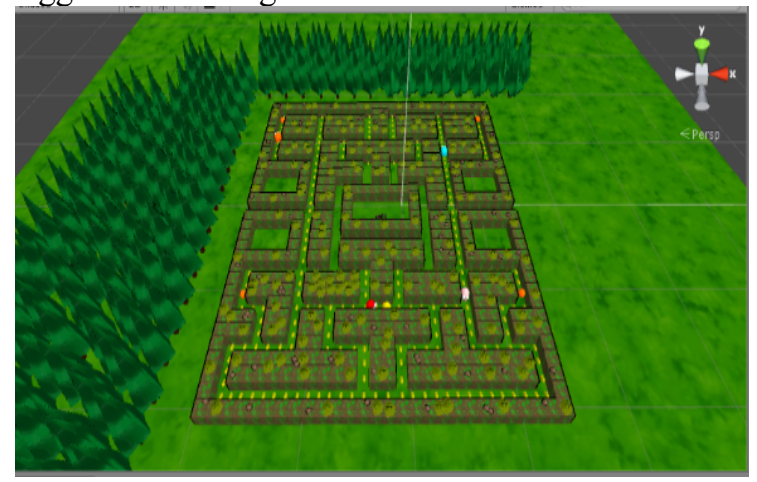

Gambar 9. Desain 3D Permainan
Gambar 10 adalah menu pilihan yang telah disediakan pada permainan. Bahkan terdapat dua arena yang dapat digunakan. Menu pilihan mencakup arena, tutorial, credit dan exit.

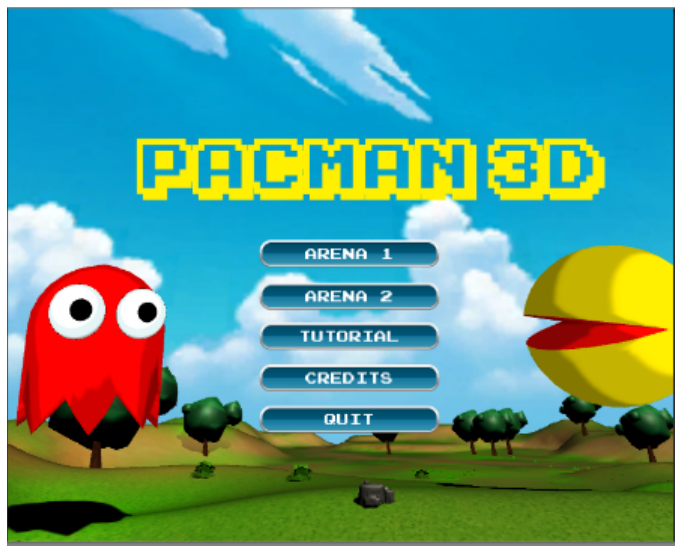

Gambar 10. Menu pada Permainan

Gambar 11 adalah tampilan dari menu tutorial yang berisi beberapa intruksi dari permainan, sehingga dapat memudahkan player untuk memahami aturan-aturan dalam permainan

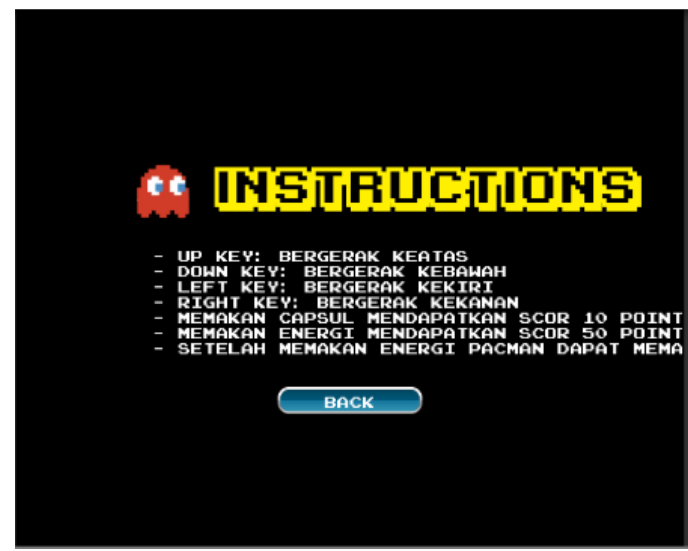

Gambar 11. Menu Intruction

Gambar 12 menunjukkan pencipta dari permainan sehingga pengguna permainan nantinya memiliki pemahaman terkait pencipta dari permainan tersebut

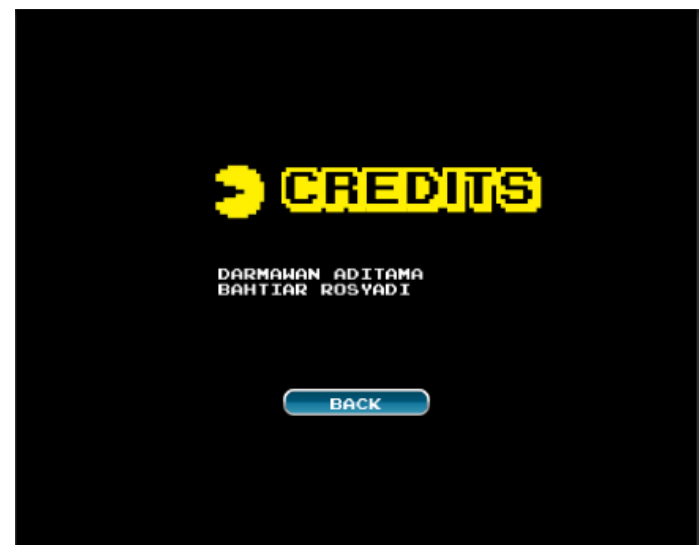

Gambar 12. Menu Credit 
Gambar 13 menunjukkan simulasi permainan sedang dilakukan. Ghost yang memiliki kecerdasan buatan A* (A Star) sedang mengejar player. Dengan kemampuan ghost yang telah diupgrade membuatnya sangat mudah untuk melacak keberadaan dari player sehingga permainan menjadi semakin menyenangkan karena ghost menjadi sulit untuk dilewati

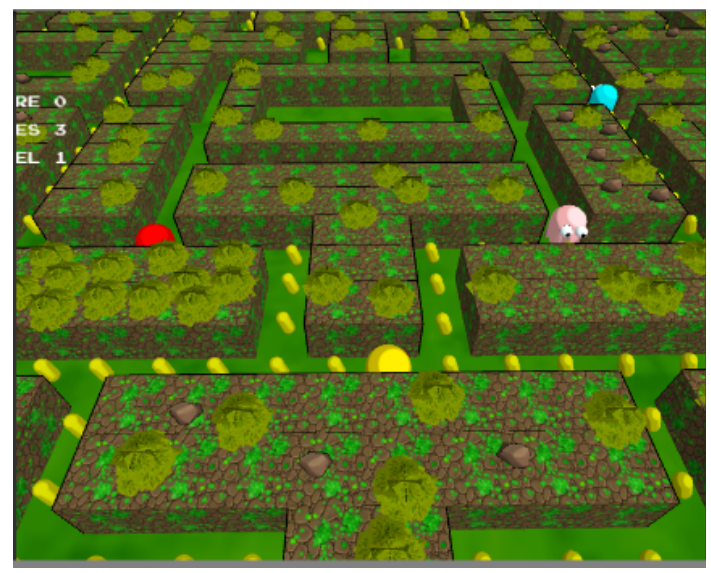

Gambar 13. Uji Coba Permainan 1

Gambar 14 menunjukkan ketika ghost berwarna merah berhasil menangkap player sehingga player mati dan permainan harus berulang dari posisi awal.

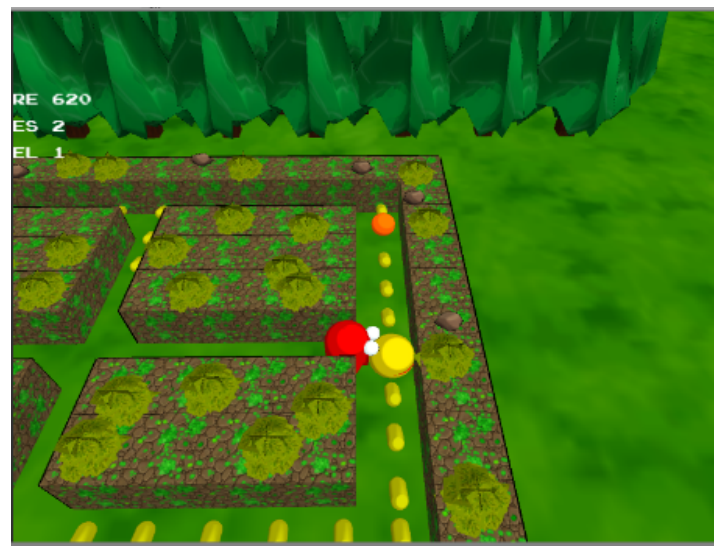

Gambar 14. Ghost Berhasil Menangkap Pacman

Gambar 15 menunjukkan posisi dimana pacman atau player dapat membunuh ghost sehingga ghost akan kembali ke posisi awal permainan berlangsung (dalam kubah tempat tinggal ghost)

Gambar 16 menunjukkan ketika permainan berakhir ketika 3 nyawa dari player telah habis. Sehingga permainan akan berulang kembali ke awal

\section{Tabel Dari Data Uji Coba}

Data Permainan adalah data yang diambil ketika permainan berlangsung. Data (Tabel I) tersebut adalah data hasil kecerdasan buatan yang ditempelkan pada masing-masing ghost.

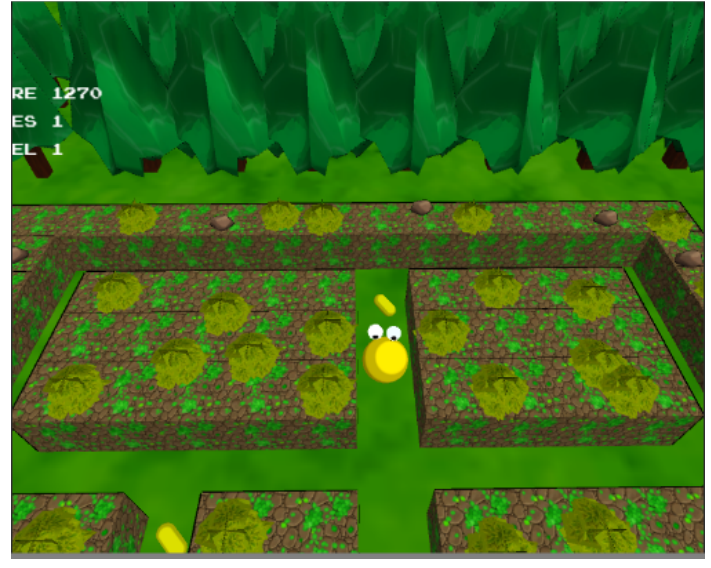

Gambar 15. Pacman Berhasil Membunuh ghost

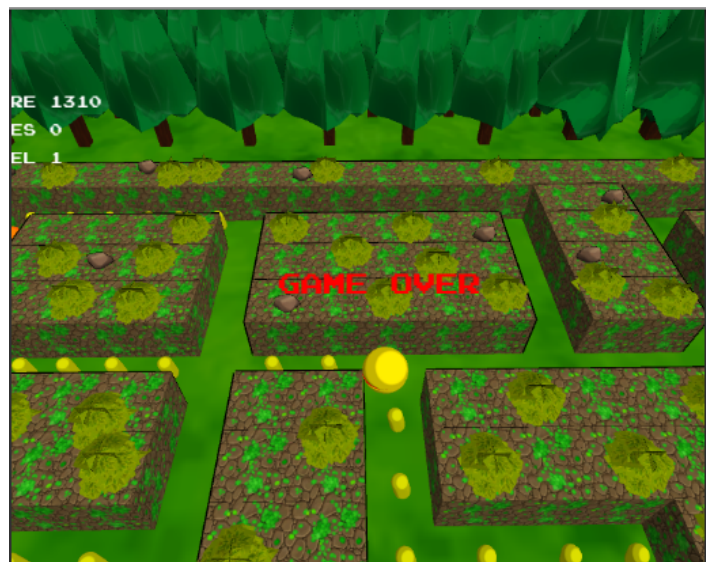

Gambar 16. Permainan Berakhir

Kecepetan ghost menemukan lokasi player menjadi data penting yang harus dioleh karena sebagai perbandingan data untuk masing-masing ghost. Hasil pada Pada Tabel I menunjukkan bahwa algoritma $A^{*}$ telah berhasi dalam menelususi target dengan waktu yang relatif cepat.

TABEL I. TABEL DATA UJI PERMAINAN

\begin{tabular}{|c|c|c|c|c|}
\hline No & $\begin{array}{c}\text { Ghost } \\
1\end{array}$ & $\begin{array}{c}\text { Ghost } \\
2\end{array}$ & $\begin{array}{c}\text { Ghost } \\
3\end{array}$ & $\begin{array}{c}\text { Ghost } \\
4\end{array}$ \\
\hline 1 & $0,5 \mathrm{~s}$ & $0,7 \mathrm{~s}$ & $0,8 \mathrm{~s}$ & $0,6 \mathrm{~s}$ \\
\hline 2 & $0,6 \mathrm{~s}$ & $0,7 \mathrm{~s}$ & $0,9 \mathrm{~s}$ & $0,4 \mathrm{~s}$ \\
\hline 3 & $0,4 \mathrm{~s}$ & $0,5 \mathrm{~s}$ & $0,5 \mathrm{~s}$ & $0,5 \mathrm{~s}$ \\
\hline 4 & $0,8 \mathrm{~s}$ & $0,6 \mathrm{~s}$ & $0,7 \mathrm{~s}$ & $0,7 \mathrm{~s}$ \\
\hline
\end{tabular}

\section{Kesimpulan}

Dari hasil pengujian dan analisa pada bab sebelumnya maka diambil kesimpulan

1. Kemampuan ghost yang memiliki kecerdasan buatan A* (A Star) dapat menemukan player semakin akurat dan efektif

2. Meningkatnya kemampuan ghost menyebabkan permainan menjadi lebih sulit untuk dimenangkan 
3. Perlu adanya penelitian lebih lanjut untuk menentukan pembatasan jarak pada sensor kecerdasan buatan $A^{*}$ sehingga player masih dapat memenangkan permainan

\section{DAFTAR PUSTAKA}

[1] A. Hermawan, Jaringan Syaraf Tiruan (Teori dan Aplikasi). Penerbit : Andi, 2006.

[2] B. Halim, "Penerapan Algoritma Fuzzy Logic Sugeno Pada Game Pac-Man," eprints, 2013.

[3] S. Kusumadewi, Artificial Intelligence (Teknik dan Aplikasinya), Yogyakarta: Graha Ilmu, 2003.
[4] A. Kristanto, Kecerdasan Buatan, yogyakarta: graha ilmu, 2004.

[5] S. Suyanto, Artificial intelligence: sarching, reasoning, planning dan learning, Bandung: Informatika, 2011.

[6] F. Harianja, "Penerapan Algoritma A* Pada Permasalahan Optimalisasi Pencarian Solusi Dynamic Water Jug," ejurnal Pelita Informatika, vol. IV, pp. 4853, 2013.

[7] H. Reddy, "cs.indstate.edu," 1312 2013. [Online]. Available: http://cs.indstate.edu/hgopireddy/algor.pdf. [Accessed 0211 2018]. 